\title{
Increasing university students' organizational skills during practical application of event management technologies in organizing events
}

\section{Aumentar as habilidades organizacionais dos estudantes universitários durante a aplicação prática de tecnologias de gerenciamento de eventos na organização de eventos}

\section{Incrementar las habilidades organizativas de los estudiantes universitarios durante la aplicación práctica de tecnologías de gestión de eventos en la organización de eventos}

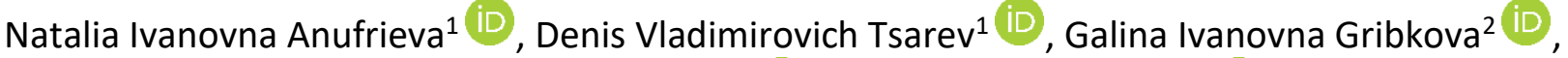
Eleonora Ilinichna Medved ${ }^{2}$ iD, Olga Igorevna Kiseleva²
\end{abstract}

\footnotetext{
${ }^{1}$ Russian State Social University, Moscow, Russia.

${ }^{2}$ Moscow City University, Moscow, Russia.
}

Corresponding author:

Natalia Ivanovna Anufrieva

Email: nata415485@mail.ru

How to cite: Anufrieva, N. I., Tsarev, D. V., Gribkova, G. I., Medved, E. I., \& Kiseleva, O. I. (2021). Increasing university students' organizational skills during practical application of event management technologies in organizing events.

Revista Tempos e Espaços em Educação, 14(33), e16729. http://dx.doi.org/10.20952/revtee.v14i33.16729

\begin{abstract}
Socio-cultural events are currently gaining increasing relevance and the problem of their organization is becoming urgent both for commercial companies and professionals in this sphere. Today, event management is becoming the leading technology for the organization of events and, notwithstanding the importance of the mastery of theoretical knowledge, only the practical implementation of event management technologies in event organization serves as a prerequisite for the development of organizational skills in professionals in the socio-cultural sphere. The conducted experimental work reveals a major discrepancy in the level of university students' mastery of organizational skills in the process of theoretical and practical training and proves the effectiveness of the latter in the development of professional mastery of socio-cultural workers. The reasons underlying the development of socio-cultural workers' organizational skills specifically in the course of practical mastery of event management technologies are identified and comprise contingency on multiple factors, the variability of the socio-cultural situation, and high competition in the market of socio-cultural services.

Keywords: Event management. Technology. Socio-cultural activity. Organizational skills. Specialist training.
\end{abstract}




\section{RESUMO}

Actualmente, os eventos socioculturais ganham cada vez mais relevância e o problema da sua organização torna-se urgente tanto para as empresas comerciais como para os profissionais da área. Hoje, a gestão de eventos está se tornando a tecnologia de ponta para a organização de eventos e, não obstante a importância do domínio do conhecimento teórico, apenas a implementação prática de tecnologias de gestão de eventos na organização de eventos serve como um pré-requisito para o desenvolvimento de competências organizacionais nos profissionais da a esfera sócio-cultural. 0 trabalho experimental realizado revela uma grande discrepância no nível de domínio das competências organizacionais dos estudantes universitários no processo de formação teórica e prática e comprova a eficácia desta última no desenvolvimento do domínio profissional dos trabalhadores socioculturais. As razões subjacentes ao desenvolvimento das competências organizacionais dos trabalhadores socioculturais especificamente no curso do domínio prático das tecnologias de gestão de eventos são identificadas e compreendem a contingência de múltiplos fatores, a variabilidade da situação sociocultural e a alta competição no mercado de - serviços culturais.

Palavras-chave: Gerenciamento de eventos. Tecnologia. Atividade sócio-cultural. Habilidades organizacionais. Treinamento especializado.

\section{RESUMEN}

Los eventos socioculturales están adquiriendo actualmente una relevancia creciente y el problema de su organización se torna urgente tanto para las empresas comerciales como para los profesionales de este ámbito. En la actualidad, la gestión de eventos se está convirtiendo en la tecnología líder para la organización de eventos y, no obstante la importancia del dominio de los conocimientos teóricos, solo la implementación práctica de las tecnologías de gestión de eventos en la organización de eventos sirve como prerrequisito para el desarrollo de habilidades organizacionales en los profesionales de el ámbito sociocultural. El trabajo experimental realizado revela una gran discrepancia en el nivel de dominio de las habilidades organizativas de los estudiantes universitarios en el proceso de formación teórica y práctica y demuestra la efectividad de esta última en el desarrollo del dominio profesional de los trabajadores socioculturales. Se identifican las razones que subyacen al desarrollo de las habilidades organizativas de los trabajadores socioculturales específicamente en el curso del dominio práctico de las tecnologías de gestión de eventos y comprenden la contingencia de múltiples factores, la variabilidad de la situación sociocultural y la alta competencia en el mercado de -servicios culturales.

Palabras clave: Gestión de eventos. Tecnología. Actividad socio-cultural. Habilidades organizativas. Formación especializada.

\section{INTRODUCTION}

The specifics of event management are shaped by numerous factors. Holding an event successfully requires meeting a variety of requirements, from the preparation of a detailed plan to the direct implementation of the event. The modern approach implies that the focus of attention in the preparation of an event lies on the interests and expectations of the client. Thus, a manager has to put much more effort into making specific decisions, consider the psychological factors, and the effect of subjective perception of the results of the work. In this case, the technical and economic techniques of production organization become secondary.

Socio-cultural events are of great importance for the corporate activity of any company. They help to resolve the internal issues of the company and reduce social conflicts and allow increasing employees' motivation and the coherence of the team since the events are dedicated or timed to a special occasion, event, or date and serve as an excellent means of the company's communication 
with the outside world. The organization of events is realized to produce a positive effect on the opinions of their participants, establishing business contacts, and exchanging experiences.

Event management and the training of professionals in this sphere are currently actively developing in Russia. There is a consistent process of the development of institutional features of the event industry and the set of certain requirements for specialists in this area is taking shape. Knowledge of event organization technologies allows understanding the specifics of organizing and holding events, however, only the practical implementation of event management technologies in the organization of an event serves as a precondition for the development of organizational skills in socio-cultural sphere professionals.

\section{LITERATURE REVIEW}

The methodological foundation for the study is formed by Russian and foreign works on management, marketing, IT, economics, sociology, and business. Scientific literature explores various types and forms of events and the principles of their organization. S.G. Ermakov and others indicate that event management comprises a set of measures for creating striking and memorable events that not only meet society's needs for learning, development, recreation, and new experiences, but also promote the companies developing innovative products and services that work in the field of management consulting and systemic integration (Ermakov et. al., 2017). T. Brown and P. Stokes propose an original theory suggesting that "events can be depicted as a "domain" which connects event professionals to a "community". The themes emerging revealed that there are modes of working, shared values and practices, a shared identity, and a desire to work as a wider collective to maintain and enhance knowledge and practice, which are in keeping with a community of practice framework" (Brown \& Stokes, 2021, p. 224).

Asanova (2012) argues that event preparation requires original and creative solutions. Of importance is the consistency of event ideas and brand development, hitting the target audience, and detailed organization. The more complex the event, the more difficult it is to coordinate and obtain the necessary permits for the event, to ensure technical support. The main components of event management are research, development, planning, coordination, evaluation, organization, control, holding, and summarizing the event (Holzbaur \& Jettinger, 2007). The creation of an event begins with the research and development phase of the project (Gerasimov et. al., 2009).

laroshenko (2013) indicates that an organizer has to pay due attention to each component to meet all the desires and expectations of the client:

1) the plans of all participants involved in the event organization including partners and sponsors;

2) determining the goals and expected results of the event desired by the partners and sponsors;

3) the creation of an original idea characterized by a creative approach in practical implementation;

4) immersion into the experience of creating events of this type with the study of concepts, visual and semantic characteristics, and methods of development of the previously organized events;

5) creating a clear timeline and deadline for the event, its inclusion in the work schedule, accounting for the target audience and weather conditions;

6) the qualitative and quantitative assessment of all available resources (human, material, technical, financial, organizational) required for the planned event, and recording said resources.

According to Avanesova (2006), the development of an event is divided into the creative part (creating the program and content of the event depending on its goal and objectives, the needs of the audience, the expected results) and the administrative part (creating the briefing for the participants, the organizer, and contractors). The development stage is associated with a constant 
search for new ideas assisted by the methods of brainstorming and mind maps (relationship diagrams) (Barlow \& Møller, 2017), as well as cross-cultural communication skills (Shafazhinskaya et al., 2019).

The event planning stage involves solving the specific organizational tasks, determining the deadlines, taking actions to cause a public resonance, involving event agency experts, and negotiating with the media representatives (Vartanova, 2014).

\section{METHODS}

To determine the specifics of event management as a technology for the organization of events, identify the specific features of event management implementation in Russia, and provide a classification of modern events, we use the following theoretical and experimental research methods:

1) Theoretical methods - scientific literature analysis and a generalization of the modern practice of event management in Moscow.

2) Experimental work aimed at comparing the effectiveness of theoretical and practical mastery of event management technology in the development of organizational skills in sociocultural sphere professionals was conducted during the 2020-2021 academic year at the Russian State Social University (RSSU) and the Moscow State University of Culture (MSUC) training specialists in this sphere. In addition, we assessed the statistical data on the number of mass events held in Moscow in 2020 and 2021 and the number of their visitors and conducted pedagogical observation and the assessment of quantitative and qualitative indicators of the results of students' work on projects (calculating the number and surveying the participants in the events to determine their satisfaction with the organization and content of the events).

The first stage of the study involves sociological research - we conducted an analysis and evaluation of statistical data, specifically the quantitative and qualitative results of 16 large-scale mass events held in Moscow in 2020 and 2021. The quantitative data were selected based on the criterion of no less than 1,000 event attendees; the number of visitors of the same events in 2020 and 2021 was compared; the percentage of events held by professional agencies and highly specialized institutions was determined; the ratio of visitors of different ages was calculated; the quality of event results was assessed according to the visitors' feedback on official event websites and in social media.

The second stage of the study includes experimental work on the practical mastery of event management technologies in the process of the development of organizational skills in sociocultural sphere workers that was conducted from September 2020 to May 2021 in RSSU and MSUC with the participation of 3 groups of students of the "Social and Cultural Activity" direction of training in these universities (the total sample of the experiment is more than 30 students). The experiment involved pedagogical observation of the experimental group of students (30 people) lasting from September 2020 to May 2021.

The final stage of the study involves the analysis and evaluation of the qualitative and quantitative indicators of the results of the students' work on the projects. It involved calculating the number and verbally surveying the participants of the events to determine the degree of their satisfaction with the organization and content of the events. The sample of the verbal survey equals 398 visitors to the first event and 604 visitors to the second event. At the end of the events, the visitors were asked simple questions: "Are you satisfied with the organization of the event?", "Did you enjoy the event?", "Was the event useful for you?", "Would you attend the event again?". The survey participants were not specially selected. All attendees were asked the questions but not everyone participated verbally (398 of over 600 participants in one event and 604 of over 800 
participants in the other). The resulting data were manually processed by calculating the total of "yes" and "no" responses.

\section{RESULTS}

The theoretical portion of the study allows determining the specifics of event management as an event organization technology and the specific characteristics of event management implementation in Russia, as well as to provide a classification of modern events.

A specific feature of event management is the variety of the deployed technologies ensuring successful planning and realization of different types of events (Goikman, 2010). Event management theory distinguishes between the following types (Vartanova, 2014):

- seminars;

- competitions;

- refresher courses;

- meetings and sessions;

- anniversaries.

The events organized by various event agencies include (Shumovich, 2008):

- fundraisers;

- greetings;

- ceremonies;

- celebrations;

- sports competitions;

- concerts;

- musical performances;

- mass festivities.

Event organization in Russia demonstrates specific features shaped by the Russian mentality. Firstly, event agencies offer a wider selection of services. Secondly, mass events are increasingly guided by the European experience. Thirdly, celebrations are the most popular type of event in Russia and when held, last until the morning of the next day. Fourthly, sports events and brand promotion in shopping malls are especially popular among youth (Shafazhinskaya et al., 2019). The market of event marketing in Russia is only developing, this sphere of activity cannot be considered fully formed (Mann, 2017). Many companies start the preparation for the event only a few days prior to it which majorly complicates the organization process and makes it more expensive. This entails the need for improving the level of professional training of event managers as it determines the result of the event organization.

The specifics of event management technologies call for the practical mastery of organizational skills. Developing and successfully holding an event requires creating the general concept, carefully analyzing the needs of the audience, determining the goals and objectives of the event, accounting for all the intricacies and characteristics of each type of event, planning the budget, resources, and personnel policies associated with professional event management. Therefore, the empirical portion of the study involves experimental work aimed at comparing the effectiveness of theoretical and practical mastery of event management technologies in the development of organizational skills in socio-cultural sphere professionals that was conducted during the 2020-2021 academic year in the RSSU, MSUC, and other universities training specialists in this sphere.

At present, culture in general is being actively promoted in Russia at the state level through its "introduction" into the lives of people, especially the younger generation - preschoolers and school and university students. Various campaigns and events making the cultural life of the city more accessible and understandable for people are being organized. There are numerous different campaigns in Moscow, the most popular of them being: 
- "Night at the Museum" (an annual city-wide event with the participation of city, federal, private, and departmental museums and galleries; the event is traditionally held on the third Saturday of May);

- "Biblionight" (an annual social and cultural event dedicated to reading held in April throughout Russia; as a part of this event, night libraries, bookstores, literary museums, and art spaces expand the time and format of their work);

- "Night at the Theater" (a series of free events dedicated to Theater Day on March 27 and including performances, excursions to Moscow theaters, and other events);

- "Night of Art" (an annual cultural and educational event involving museums and theaters, exhibition and concert halls, libraries and cultural clubs holding themed events, this time, both in offline and online format);

- the Circle of Light Festival (an annual event in which lighting designers and 2D and 3D graphics professionals use Moscow's architectural space as an object for multimedia and light installations) (Official website of the Department of Culture of Moscow, n.d.).

The conducted sociological research involving the analysis and evaluation of statistical data, namely the quantitative and qualitative results of public events held in Moscow in 2020 and 2021, shows that the first positions in terms of the number of held events are occupied by:

- corporate events involving various events in support of business ideas performing the management, corporate communications, training, marketing, and work incentive functions;

- marketing events aimed at finding contacts with the target audience;

- seminars and conferences for information exchange, discussions, debates, finding consensus and solutions, education, and establishing relationships;

- festivals - mass events of a certain theme;

- private events organized by order of an individual or a small group;

- charity events created to help those in need;

- sports events in which the guests are both observers and participants;

- secular events small groups of people on a particular occasion of a religious, cultural, or social nature;

- state, political, and civic events on a municipal and federal scale (Laux \& Liermann, 2006).

Universal event agencies organize $19.8 \%$ of events while $80.2 \%$ are organized by highly specialized event agencies. The top-20 of the leading event marketing companies in Moscow currently include Eventum Premo, WORLDS, DoctorTeam, Redday event, PAPA CARLO, MaxMedium, and other companies. They hold successful events of different genres and topics at the national and international levels.

The data on people's attendance at the events in Moscow is recorded on the website of the Institute of Socio-Cultural Programs (Official website of the Moscow Institute of Social and Cultural Programs, n.d.). Considering the statistical data, it should be noted that the "Night at the Museum" event gathers more and more participants every year. This is due to the fact that people often simply lack enough free time, especially in the daytime. On the day of the event, visiting the site is possible late at night and is free of charge. On such days, the events are attended by people who do not usually go to museums and cultural institutions (Goikman, 2010).

"Night at the Museum" is an event that involves cultural and educational goals and is already being held internationally in 42 countries. It is dedicated to World Museum Day celebrated on May 18. Every year on this date, museums and cultural institutions work late into the night, and some even during the night. Due to the pandemic, the 14th "Night at the Museum" in 2020 was held in Moscow online for the first time. Despite this, the event was massive, memorable, spectacular, and vibrant. From May 16 to 17, 2020, over 50 galleries and museums of the capital participated in the event. The event was organized by the Department of Culture of Moscow and the "Mosgortur" agency. Due to the coronavirus pandemic, the event was held online, so 849,983 people were able 
to attend the event which exceeds the number of participants in 2019 by more than one and a half times. This was the first time such an event had ever been held.

The online events being part of "Night at the Museum" were organized on the official websites of the galleries and their social media accounts. The most visited museum was the Memorial Museum of Cosmonautics as the event "The 60s: Our Space House Concert" was visited by 114,186 people and 108,332 Internet users took part in the online competition "Space vs. Science Fiction".

Among the leaders is also the Museum of Moscow whose theatrical and family festival "City in a Window" gathered 74,470 participants. The virtual exhibition "Comics," "The Master and Margarita", and the "Mikhail Bulgakov in Paper Cinema" event held at the Bulgakov Museum brought together 61,777 visitors. The online tour of the Gulag History Museum gathered 60,385 portal users, and the Zoo Museum attracted 57,854 people. In addition, high attendance was noted in such museums as Tsaritsyno Museum-Reserve, the Pushkin State Museum, Multimedia Art Museum, "Northern Tushino" Museum and Park Complex, and K.G. Paustovsky Museum. Many events were designed for the creative development of children (Pereverzeva et al., 2020).

Aside from the traditional lectures and excursions, the organizers of "Night at the Museum" introduced completely new forms of communication with the visitors. For instance, the State Darwin Museum and the Artel of Free Artists jointly created a sort of an art-space "Shadow of the Cage art-laboratory performances", as well as an unusual quiz-lecture about sleep "In the Kingdom of Morpheus" telling about what sleep is, what kinds of sleep there are, and why we need it. The museum of the iconic poet held a Zoom lecture with sign language interpretation "You can see great things at a distance" where everyone, including people with hearing impairments, could learn interesting facts about the life and work of Sergei Yesenin. The State Museum and Cultural Center "Integration" named after N.A. Ostrovsky chose an unusual online quiz format.

Russia has a very sensitive and respectful attitude to Victory Day, events devoted to the veterans and the victims are organized annually. In 2020, in the year of the 75th anniversary of the Victory in the Great Patriotic War, various online events were organized due to the pandemic. The Museum of Vladimir Vysotsky organized a video livestream telling about the poet's work on military subjects; a story about the Battle of Moscow was presented by the Museum of Defense of Moscow; a distance excursion was organized by the Museum and Memorial Complex "History of the T-34 tank".

Many interesting author's events are also held in Moscow. An example of this can be the author's lecture by the famous Moscow tour guide Egor Sartakov at the Gogol House, the Moscow Tea Party holiday program held at the iconic Garden Ring Museum, the Kuskovo Estate Museum where the curator tells about the legends and beliefs of the estate and, of course, the most popular programs with children's theater performances and the "Night of Museum Travels" from the Moscow Museum taking the visitors on a video tour of the iconic museums of New York, Sydney, London, Amsterdam, Stockholm, and Russian cities (Pereverzeva et al., 2020).

It is worth noting the great role of the Department of Culture of Moscow that actively assists the organization of events. Together with the modern social media VKontakte the audience of which reaches 100 million people a month, they implemented new interesting online projects. The website and the app broadcasted events from Moscow's main museums: the Memorial Museum of Cosmonautics, the GULAG History Museum, the Moscow Museum, and the Bulgakov Museum. The translations were watched by not only Moscow residents but also viewers from all across Russia and the CIS countries.

The "Biblionight-2015" event devoted to personal diaries was held in Moscow not only in libraries but also in parks, on boulevards, in museums, and bookstores. Readers participated in a cycling quest in which the participants themselves chose the path to follow using the points marked on the map and used a special mobile app containing a map with the Moscow libraries being marked 
and listing the schedule of events in each of them where all participants could find clues for the quest.

The event was held in Moscow on the night of April 24-25, 2015. Traditionally, it is held not only in the capital but also in other cities of the country since 2012. According to the results, the "Biblionight 2015" event was attended by 150 thousand people. Half of all visitors were under 30 years old, and the average age was 37 . The event also involved a special project "Bibliotwilight" organized for family and children's audiences. There was also the "Writer with a Diary" event with the participation of children's writers with their personal diaries.

The "Muzeon" park opened an exhibition of book illustrations presenting more than 40 works. "Flacon" Design Factory participated in the "An Artist and a Book" project involving a specialized festival. The book illustration project included 16 masterclasses, 28 locations, and 3 lectures.

There was a project "A Citizen's Diary" initiated by Moscow students, among which there were designers and culturologists. In the Turgenev Library, excerpts from collected Internet diaries were read out by theater actors, and a video broadcast was organized by graduates of the Higher School of Economics Design School.

The conducted experiment involves three groups of students of the "Social and Cultural Activity" direction of training in the RSSU and MSUC who were involved in the organization of the city events as a part of their internship at the Department of Culture of Moscowк. The students took part in preparing the opening of the House of Culture of the RSSU serving as a place for concerts of different types of music, literary and dance performances, contests, and festivals, and KVN and StandUp evenings.

At the first stage, the students conducted a detailed analysis: determined the target audience, studied the interests of the public and the capabilities of the institution, developed a general scheme of the event, and clarified the details of the organization process. The second stage involves the creative process:

- developing the idea of the event;

- creating the visual concept;

- developing a detailed scenario plan;

- budgeting;

- preparing the venue and the design project for the event;

- decorating the opening venue;

- selecting the necessary equipment;

- recruiting the staff: a host, a sound engineer, artists, a photographer, and a videographer;

- organizing catering;

- souvenir production;

- creating the show program, booking artists.

The opening itself was the third stage of the event organization fully entrusted to the students. The roles within the group were distributed starting from the event coordinator tasked with accounting for each detail and ensuring compliance with the scenario, controlling the timing, work with the audience and guest artists, the actions of the staff, the creation of a festive atmosphere throughout the event, etc. (Thomas, Hermes, Loos, 2008). Given that all students of the "Social and Cultural Activity" direction of training master the skills of creative activity (pop singing, modern dance, acting, etc.) as a part of their training, a part of the students were involved in the preparation of the show program. The design project and visual concept of the event were developed by the experiment participants in collaboration with students of the "Design" direction of training.

Overall, the students were independently preparing the venue and design project for the event, decorating the site of the event, selecting the necessary equipment, recruiting personnel and 
distributing the roles between each other, ordering the production of souvenirs, compiling the show programs, and negotiating with outside artists. A special role in the organization of the opening was attributed to the decoration of the venue and creating a festive atmosphere. The students made an entrance arch from balloons and garlands of artificial flowers and an installation with the symbols of the House of Culture - a guitar, a collection of notes, a microphone, and rolls of posters. Artificial flowers and inflatable balloons were also used in the decoration of the concert hall.

The format of the event chosen by the students ended up being a concert with university students, a musical quiz, a contest for the audience with prizes for the winners, and an exhibition about the history of pop art. An opening is a special event associated with the launch of a new project and creating the institution's reputation. Therefore, the organizers paid close attention to the media and negotiated with local newspaper journalists and Internet sources to cover the event and publish reports on it. Negotiations were also held with sponsors and partners: in this case, it was the stationery store chain "Komus" and the youth clothing brand "Generation X". The estimated number of visitors at the opening of the House of culture was 400 people.

The second event independently organized by the students for their practical mastery of event management technologies is an education exhibition with the participation of the RSSU where the exhibitors were able to visually present their services to the potential consumers. "Education fairs" have been held in Moscow for over 10 years at large venues for the general public.

The effective organization of this event format is arranging tables with leaflets and brochures and chairs and armchairs for visitors. It is also possible to incorporate the business program of the event - showing universities' presentations on the educational programs and admission requirements. For instance, the Russian forum "Education Industry 2020" deployed two programs of event organization and built a separate section for forty exhibitors. The exhibition was attended by 17,000 educators, school alumni, and their parents. The forum also had a business hall where the exhibitors held educational and informational events, offering services, and giving consultations (Sergeeva et al., 2021). Close communication with the target audience has allowed achieving great results in the organization of the education fair. As noted by K. Borodako, "the market for congresses, conferences, trade shows, and business events attract clients and contractors from around the world, so competition between firms motivates them to apply advanced technologies that enable faster and easier cooperation" (Borodako et al., 2021, p. 148).

A fair is an effective type of event for presenting educational services to consumers, attracting applicants to the university, and promoting the brand of the institution. All of this is possible with the right approach to organizing the event. This requires the appropriate organization of the exhibition area, choosing the fitting format of interaction with the visitors, preparing handouts and the informational program, and decorating the site. The students of the experimental group were involved in the general organization of the event by the Department of Education of Moscow and were preparing their own exhibition area thus obtaining the skills of teamwork and negotiation with the organizers of events of different levels. Participation in this event has allowed to:

- increase the number of graduates familiar with the university's training programs;

- present new directions and forms of training;

- explore the educational needs of the modern generation;

- assess the level of interest in the new programs;

- determine the professions most attractive for graduates.

The students of the experimental group independently chose the site for the event, developed the event plan, announced the university's participation in the event on social media and the official university website, sent out information to the management of schools and colleges, drew in visitors through the media, designed, assembled, and artistically decorated the university stand, desks, and exhibition area, developed the corporate identity of the section, designed and 
printed the polygraphic products (flyers, ads, banner), shot a video to be played on repeat on the screen in the exhibition area, distributed promotional material and talked with graduates, and held the opening ceremony of the fair, providing musical accompaniment and the performance of vocalists and dancers.

In the process of the entire preparation of the event and its realization, the students' attention was pointed to the precise coordination of each of the components. At the moment of the fair opening, all participants and personnel were at their places ready to greet the visitors. The goals and results of the preparation of the fair were clearly defined. The adopted quantitative indicator was 500 flyers to be handed out to the visitors; the determined qualitative indicator was the degree of potential applicants' interest in the training programs offered by the university assessed through the number of questions on admission asked by the visitors, the time spent by them studying the materials, and their desire to get an individual consultation on entering the university.

The creation of the university image, the establishment of partnerships, and informing the audience was ensured by a video presentation filmed by the students as a part of the project. The purpose of the presentation was to arouse the interest of potential applicants to the educational services offered by the university.

After the completion of the training of the socio-cultural sphere specialists, pedagogical observation, analysis, and evaluation of the qualitative and quantitative indicators of the results of the students' work on the projects (calculating the number and surveying the participants in the events to determine their satisfaction with the organization and content of the events) provide the following results:

- both events have drawn a greater audience than planned (the opening was attended by over 600 people instead of the estimated 400; more than 800 flyers were handed out at the education fair instead of the planned 500);

- the survey of the participants in the events after their end shows that the opening of the House of Culture was enjoyed by the spectators (65\%), elicited neutral feelings (32\%), and did not leave any impression (3\%) which can be considered a success; at the end of the education fair, each fourth visitor reported going to the RSSU section and receiving handouts which indicates that $25 \%$ of the event participants received information about the educational services of the university as a result of the efforts of the exhibition organizers;

- the qualitative indicator of the students' success in organizing and holding the two events is the characteristic of the concert and the fair provided by the visitors in social media, increased interest of the public in the held socio-cultural events, and the rise in the number of followers of the "RSSU Live" YouTube channel.

In the mid-1990s, the Russian economy began to develop in a new way and the event management profession has become one of the most demanded on the communications market. Statistics show that after a successfully held event, brand recognition increases by over $30 \%$ which is quite substantial in modern realities. According to the analysts of the World Travel and Tourism Council, in 2020, every 10th job in the world belongs to the event management industry, and the average income in event management in two years is going to increase by another quarter.

\section{DISCUSSION}

At the present moment, there are very few specialists in Russia dealing exclusively with event management at the professional level. The skills necessary for this profession are obtained by psychologists, artists, teachers, and advertisers. Russia currently has a very small number of courses training event managers and no educational institutions focusing on their training. This fact is noted by E.L. Vartanova regarding a special sphere of work - the media business (Vartanova, 2014). S.G. Ermakov and others (2017) indicate the shortage of existing approaches to modern events and A.V. 
Shumovich (2008), examining the technologies and practice of event management on the example of the most successful events, emphasizes the need for the development of special skills in the professionals in this sphere.

As indicated by N.N. Iaroshenko (2013), the event management discipline is not included in training programs for specialists in the socio-cultural sphere. Event agencies train their employees on their own, recruiting interns and selecting the best of them (Brown, Stokes, 2021; Borodako et al., 2021). Therefore, the mastery of event management technologies in the course of practical development and organization of a specific event serves as a precondition for the development of organizational skills in future socio-cultural sphere specialists. N.E. Shafazhinskaya and others (2019) also note that the mastery of world experience improves the development of professional competencies.

The more complex the event format is, the greater responsibility and number of tasks are put on the event manager. An event manager has to possess creative and organizational abilities, leadership qualities, creative and analytical thinking, a sense of style, responsibility, stress resistance, striving for new knowledge and self-improvement, communication skills, and focus on the result (Goldblatt, 2015). These qualities can only be formed in practical activity which demonstrates greater effectiveness in the process of mastering event management technologies compared to theoretical training.

\section{CONCLUSION}

The conducted study has reached its goal of proving the effectiveness of practical mastery of event management technologies in the process of organizational skills development in sociocultural sphere professionals, as well as concluding on the need for an exclusively practical form of mastering event management technologies. The development of a specific event here and now is a precondition of the development of organizational skills in socio-cultural sphere specialists. Preparation of a mass event is a complex and multistage process, and in the course of the entire cycle of the event preparation, as well as in the process of holding it, the students' attention was pointed to the precise coordination of each of the components.

Limitations of the present study are associated with observing students from only one year of study without comparing their achievements with those of students from other years and other universities, as well as with the involvement of the students in two projects. The present study will be continued with consideration of these factors. Objective results can be obtained in a greater scale study of the research problem. The perspectives of implementation of the present study are found in the use of the study results in the development of training programs for socio-cultural sphere workers, as well as in the fact that it can evince the need to introduce the event manager specialty into the Russian educational standards. The results of the study can be of use to the employees of event agencies and state institutions of culture and leisure.

Authors' Contributions: Anufrieva, N. I.: conception and design, acquisition of data, analysis and interpretation of data, drafting the article, critical review of important intellectual content. Tsarev, D. V.: conception and design, acquisition of data, analysis and interpretation of data, drafting the article, critical review of important intellectual content. Gribkova, G. I.: conception and design, acquisition of data, analysis and interpretation of data, drafting the article, critical review of important intellectual content. Medved, E. I.: conception and design, acquisition of data, analysis and interpretation of data, drafting the article, critical review of important intellectual content. Kiseleva, O. I.: conception and design, acquisition of data, analysis and interpretation of data, drafting the article, critical review of important intellectual content. All authors have read and approved the final version of the manuscript.

Ethics Approval: Not applicable.

Acknowledgments: Not applicable. 


\section{REFERENCES}

Asanova, I.M. (2012). Organizatsiia kulturno-dosugovoi deiatelnosti: uchebnik [Organization of cultural and leisure activities: textbook]. Moscow: Akademiia.

Avanesova, G.A. (2006). Kulturno-dosugovaia deiatelnost: teoriia i praktika organizatsii: uchebnoe posobie [Cultural and leisure activity: Theory and practice of organization: textbook]. Moscow: Aspekt Press.

Barlow, J., Møller, C. (2017). Zhaloba - podarok. Kak sokhranit loialnost klientov v slozhnykh situatsiiakh [A complaint is a gift: recovering customer loyalty when things go wrong]. Moscow: Olimp-Biznes.

Borodako, K., Berbeka, J., Rudnicki, M. (2021). Technology used in knowledge management by global professional event services. JGIM, 29(1), 145-163.

Brown, T., Stokes, P. (2021). Events management as a community of practice. J Hospital Tourism Insights, 4(2), 224242.

Ermakov, S.G., Makarenko, lu.A., Sokolov, N.E. (20107). Event-menedzhment: obzor i sistematizatsiia podkhodov k organizatsii meropriiatii [Event management: review and systematization of approaches to organizing events]. Administrative Consulting, 9, 140-148.

Gerasimov, S.V., Tulchinskii, G.L., Lokhina, T.E. (2009). Menedzhment spetsialnykh sobytii v sfere kultury: Uchebnoe posobie [Management of special events in the sphere of culture: Textbook]. Saint Petersburg: "Lan” Publishing House.

Goikman, O.la. (2010). Organizatsiia i provedenie meropriiatii: uchebnoe posobie [Organizing and holding events: textbook]. Moscow: INFRA-M.

Goldblatt, J.J. (2015). Special events: event leadership for a new world. New Jersey: Wiley.

Holzbaur, U., Jettinger, E. (2007). Event-menedzhment [Event management]. Moscow: Eksmo.

laroshenko, N.N. (2013). Istoriia i metodologiia teorii sotsialno-kulturnoi deiatelnosti: uchebnik [History and methodology of the theory of socio-cultural activity: textbook]. Moscow: Moscow State University of Culture.

Laux, H., Liermann, F. (2006). Osnovy organizatsii. Upravlenie priniatiem reshenii [Fundamentals of organization. Decision-making management]. Moscow: Delo i servis.

Mann, I. (2017). Marketing bez biudzheta. 50 rabotaiushchikh instrumentov [Marketing with no budget. 50 instruments that work]. Moscow: Mann, Ivanov \& Ferber.

Official website of the Department of Culture of Moscow (n.d.) Available: http://kultura.mos.ru

Official website of the Moscow Institute of Social and Cultural Programs (n.d.) Available: http://www.miscp.ru

Pereverzeva, M.V., Kats, M.L., Ovsyannikova, V.A., Aksenova, S.S., Yushchenko, N.S. (2020). Technology and innovation in schoolchildren training: development of musical and acting skills. Univ J Educat Res, 8(7), 2766-2771.

Sergeeva, M.S., Sokolova, A.S., Karavanova, L.Zh., Skudnyakova, E.V., Ishchenko EN. (2021). Technology Of Forming A Multicomponent Organizational Structure Of A Continuous Pedagogical Education System. Propósitos y Representaciones, 9(SPE2). http://dx.doi.org/10.20511/pyr2021.v9nSPE2.991

Shafazhinskaya, N.E., Shcherbinina, V.M., Ivanova, E.Y., Belyakova, T.E., Pereverzeva, M.V. (2019). Learning about world art culture as a method of forming a universal cross-cultural communication competence. Human Soc Sci Rev, 7(6), 1225-1229.

Shumovich, A.V. (2008). Velikolepnye meropriiatiia: Tekhnologii i praktika Event management [Magnificent events: technologies and practice of event management]. Moscow: Mann, Ivanov \& Ferber.

Thomas, O., Hermes, B., Loos, P. (2008). Reference model-based event management. Int J Event Manage Res, 4(1), 816.

Vartanova, E.L. (2014). Osnovy mediabiznesa: uchebnik dlia studentov vuzov [Fundamentals of media business: university textbook]. Moscow: Aspekt Press.

Received: 21 July 2021 | Accepted: 22 September 2021 | Published: 15 November 2021 